成ろべく少量なるべし.

\title{
8. 防腐劑
}

含有すべから亦。

9. 人工甘味質

含有すべからす.

10. 有害金屬

含有すべからず.

11. 著色料

アナトー,クルクミン其他無害性の植物色素及人工著色料なること要す

12. 細菌聚落數

$10 \mathrm{~g}$ 中 100,000 個以下なるべし.

\section{フェノール樹脂製飲食器具檢查法}

\section{緒㝘}

フェノール樹脂製飲食用器具とはフェノール類とフォルムアルデヒードの絔合物 (所謂フェノール樹脂) を使用せる拎食器, 割岽具其他领食物の調製器, 容器, 眝藏 器又は量器を謂ふ.

\section{試驗}

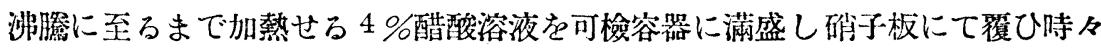
㩭挥しつつ 30 分間放置せる後其浸液に就き次のフォルムアルデヒード及フェノー ルの試驗を施行すべし.

1. 檢夜 $5 \mathrm{cc}$ を試驗管に取り硫酸 $1 \mathrm{cc}$ を發熱せざる棈注意して混和し次にフク シン亞硫酸溶液 $5 \mathrm{cc}$ を加へ 試驗管を栓塞し輕く搖盜したる後一時間放置するに紫 色乃至紅色を呈すべらす。

2. 檢液を $5 \mathrm{cc}$ 試驗管に取りブローム水を滴加し $1-2$ 時間放置するに微に润 濁を呈することあるす帶黃白色の沈垽を生ずがらす. 